Rountree, P. M. (1951). J. gen. Microbiol. 5, 673-680.

\title{
The Role of Certain Electrolytes in the Adsorption of Staphylococcal Bacteriophages
}

\author{
By PHYLLIS M. ROUNTREE \\ Fairfax Institute of Pathology, Royal Prince Alfred Hospital, \\ Sydney, Australia
}

SUMMARY: The role of electrolytes in the adsorption of the citrate-sensitive staphylococcal typing-phages and the citrate-insensitive phage $K$ on to their propagating strains was studied in broth $+\mathrm{Na}$ citrate and in distilled water $+\mathrm{CaCl}_{2}$, $\mathrm{MgCl}_{2}$, and $\mathrm{NaCl}$. Some phages when in the free state were partially inactivated by

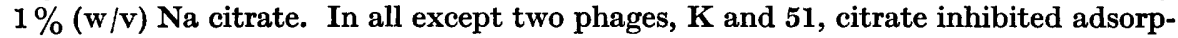
tion in broth; adsorption occurred in distilled water. Three phages, 7, 42B and 42E, had a specific requirement of $50 \mu \mathrm{g}$. $\mathrm{CaCl}_{2} / \mathrm{ml}$. for adsorption. With the remainder, the requirements of $\mathrm{CaCl}_{2}$ varied from 5 to $400 \mu \mathrm{g}$. $/ \mathrm{ml}$.; similar amounts of $\mathrm{MgCl}_{2}$ acted equally well.

With the citrate-sensitive phages adsorption in $\mathrm{NaCl}$ was variable and, where it occurred, recovery of viable phage from cells infected in $\mathrm{NaCl}$ was less than from cells infected in $\mathrm{CaCl}_{2}$. These phages appear to have a specific requirement of divalent cations for adsorption, suggesting that adsorption and penetration are enzymic in character.

The electrolyte requirements of the citrate-insensitive phage $\mathbf{K}$ were related geometrically to the valence of the cations used, $5 \mu \mathrm{g}$. $\mathrm{CaCl}_{2}$ or $\mathrm{MgCl}_{2} / \mathrm{ml}$. or 25 $\mu \mathrm{g} . \mathrm{NaCl} / \mathrm{ml}$. giving optimum adsorption.

Early in the study of bacteriophage phenomena it was observed that citrate or oxalate in the media prevented multiplication of certain phages. On the basis of such observations Burnet (1933) proposed that bacteriophages should be divided into 'citrate-sensitive' or '-insensitive', and showed that this sub-division was of value in the classification of phages which lysed intestinal bacteria and staphylococci (Burnet \& Lush, 1935).

The mode of action whereby citrate and oxalate inhibit phage multiplication has been investigated in detail for only a few phages. The action of these substances is assumed to be due to their de-ionizing effect on calcium and/or magnesium ions, but little information is available on the role which these ions play in phage synthesis (Cohen, 1949). Delbrück (1948) described a mutant of coli phage $\mathrm{T} 4$ which required $\mathrm{Ca}^{++}$as well as tryptophan for adsorption. On the other hand, Adams (1949) showed that coli phage T5 required calcium for growth but not for adsorption. The same was apparently true for the citrate-sensitive coli phage of Elford \& Andrewes (1932), coli phage T1 (Puck, 1949), and a staphylococcal phage, 51 (Rountree, 1947). At the same time, citrate may inactivate free phage, although Adams (1949) showed that, with the coli phages, inactivation in salt solutions is due to $\mathrm{Na}$ ions rather than to citrate.

The present work studies the point in the staphylococcal phage cycle at which citrate acts and was concerned in the first instance with its effect on 
free phage and on adsorption. From this point of departure the role of $\mathrm{Ca}$, $\mathrm{Mg}$ and $\mathrm{Na}$ ions in phage adsorption has been studied.

\section{MATERIAL AND METHODS}

The typing phages of Wilson \& Atkinson (1945) and phage $K$ and their respective propagating strains were used. Certain of their characteristics have been already described (Rountree, 1949). In the adsorption tests, specific adsorption of phages on to their sensitive propagating strains was studied.

All glassware was carefully cleaned in chromic-sulphuric acid mixture and well rinsed in distilled water. Distilled water (redistilled in glass) was used to make the salt solutions and, where required, to suspend bacterial cells and to dilute phages.

Phage counts were made on plates surface-inoculated with the propagating strain, each plate accommodating four separate inocula of $0.01 \mathrm{ml}$. The media used were glucose $(0 \cdot 15 \%)$ veal broth and the same broth plus $1.2 \%$ shredded agar and $0 \cdot 01 \% \mathrm{CaCl}_{2}$.

Adsorption tests were carried out in tubes $80 \mathrm{~mm}$. long $\times 10 \mathrm{~mm}$. diam., the final volume of reactants in each tube being $1 \mathrm{ml}$.

\section{EXPERIMENTAL}

\section{Sensitivity of free phage to sodium citrate}

The phages were tested for sensitivity to $1 \%(\mathrm{w} / \mathrm{v}) \mathrm{Na}$ citrate in broth in absence of bacterial cells. The phages were diluted in broth so that the final dilution (in broth + citrate) would give an estimated count of 100-200 plaques. The results were expressed as per cent inactivation after $20 \mathrm{~min}$. in a waterbath at $37^{\circ}$ as compared with controls in broth alone. It was considered that the dilution of citrate which took place when the $0.01 \mathrm{ml}$. inoculum was spread on the agar plate was adequate to prevent any interference in adsorption of phage on to the bacterial cells.

Different batches of nutrient broth may contain variable amounts of ionizable calcium and it has been recognized (Williams Smith, 1948) that a low $\mathrm{Ca}^{++}$content may render certain batches of media unsuitable for phage growth. Unfortunately no chemical method of estimating ionized calcium is available, so no very precise information can be obtained on the concentrations of citrate which inactivate free phage in broth. However, a number of estimations made with different batches of broth and the same phages showed good agreement (Table 1).

Those phages which were almost completely inactivated by citrate belong to serological group B, which has been shown (Rountree, 1949) to be markedly unstable to heat and storage. The correlation between serological type and sensitivity of free phage to citrate is not, however, absolute, since phages $29 \mathrm{~A}, 31 \mathrm{~A}, 42 \mathrm{D}$ and 44 also belong to this serological group. Since the broth in which these tests were made contained $0.5 \% \mathrm{NaCl}$, and no inactivation of 
Table 1. Percentage inactivation of free phage in $1 \% \mathrm{Na}$ citrate broth in 20 min. at $37^{\circ}$

\begin{tabular}{cl}
$\begin{array}{c}\text { Inactivation } \\
(\%)\end{array}$ & \multicolumn{1}{c}{ Phages } \\
Nil & $44,51, \mathrm{~K}$ \\
10 & $42 \mathrm{E}$ \\
$\mathbf{3 0 - 3 5}$ & $6,7,42 \mathrm{D}$ \\
$45-60$ & $3 \mathrm{~A}, 3 \mathrm{~B}, 29 \mathrm{~A}, 31 \mathrm{~A}, 42 \mathrm{~B}$ \\
$\mathbf{7 0 - 8 5}$ & $3 \mathrm{C}, 47,47 \mathrm{~A}, 47 \mathrm{~B}, 47 \mathrm{C}$ \\
$90-98$ & $29,31,31 \mathrm{~B}, 42 \mathrm{C}, 52,52 \mathrm{~A}$
\end{tabular}

phage occurred in broth at $37^{\circ}$ in the absence of citrate, it was concluded that the inactivating effect of the $\mathrm{Na}$ citrate was due to the citrate radical and not to $\mathrm{Na}$ ions.

\section{Inhibition of phage adsorption in the presence of citrate}

Sufficient Na citrate was added to overnight broth cultures of the appropriate propagating strain to give final concentrations of $0.1,0.5$ or $1.0 \%$ $(\mathrm{w} / \mathrm{v}) \mathrm{Na}$ citrate. Phage was then added, and the mixtures incubated at $37^{\circ}$ for $20 \mathrm{~min}$., centrifuged (angle centrifuge), and the free phage remaining in the supernatant determined. Controls containing no bacterial cells were included in each test.

With phages $\mathrm{K}$ and 51 there was no inhibition of adsorption in the presence of $1 \%$ citrate. Adsorption of phages $3 \mathrm{~A}, 3 \mathrm{~B}, 3 \mathrm{C}, 6,7,42 \mathrm{~B}, 42 \mathrm{D}, 42 \mathrm{E}, 44$, 47, 47 A, 47 B and $47 \mathrm{C}$ was inhibited by $0.5 \% \mathrm{Na}$ citrate. With the more unstable phages $31,31 \mathrm{~B}, 42 \mathrm{C}, 52$ and $52 \mathrm{~A}$, it was difficult to evaluate the results since almost as much phage was inactivated in the broth and citrate controls as was adsorbed by the cells in absence of citrate. However, with phages 29 and $29 \mathrm{~A}$ definite evidence of inhibition of adsorption by $0.5 \%$ citrate was obtained. Table 2 gives the result of a typical experiment.

Table 2. Inhibition of adsorption of phage $42 \mathrm{E}$ by $1 \% \mathrm{Na}$ citrate

\begin{tabular}{clr} 
Tube No. & \multicolumn{1}{c}{ Contents } & Plaque count of sup \\
1 & Cells + phage & $11 ; 9^{*}$ \\
2 & Cells + phage+Na citrate 1\% & $300 ; 322$ \\
3 & Broth + phage & $\mathbf{4 1 8} ; 400$ \\
4 & Broth + phage +Na citrate $1 \%$ & $\mathbf{3 7 0} ; \mathbf{3 4 0}$
\end{tabular}

* In this and subsequent tables, duplicate plaque counts are presented.

\section{Adsorption of phage in the presence of electrolytes}

Calcium chloride, magnesium chloride and sodium chloride were used in tests designed to demonstrate their effect on phage adsorption. The adsorbing cells were centrifuged from 5- or 18-hr. broth cultures and resuspended in distilled water at a concentration of approximately $10^{9}$ cells $/ \mathrm{ml}$. The use of high titre phages diluted in distilled water ensured that the phage suspensions 
contained negligible amounts of electrolytes derived from the medium used for preparing the phage filtrates. The salt solutions were made up in varying strengths so that addition of $0.1 \mathrm{ml}$. volumes to the adsorption tubes would result in the final concentrations required. After incubation of the mixtures in a water-bath at $37^{\circ}$ for $20 \mathrm{~min}$. the tubes were centrifuged and plaque counts made on the supernatant fluid. Some phages were unstable in simple salt solutions and in such cases it was necessary to test the centrifuged cells for the presence of viable adsorbed phage by removing the supernatant fluid, resuspending the cells in the distilled water and then plating. The minimum concentration of each salt which permitted $90 \%$ adsorption was determined for each phage. No adsorption of phage was observed in phage + cell mixtures lacking electrolytes.

Table 3. Adsorption of phage $42 \mathrm{E}$ in presence of electrolytes

Quantities of electrolytes shown in $\mu \mathrm{g} . / \mathrm{ml}$. solution.

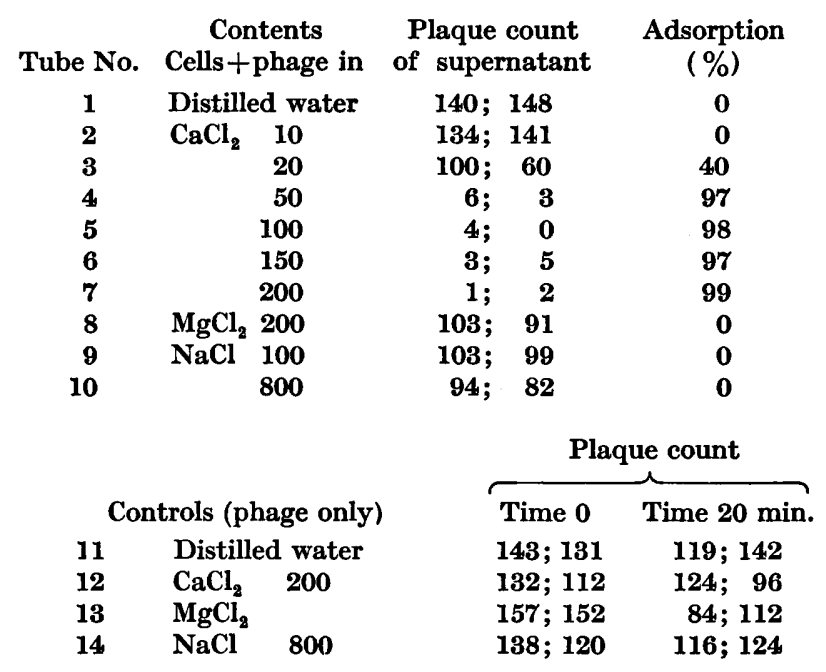

Table 3 shows the plaque counts obtained in a typical experiment using phage $42 \mathrm{E}$. The average initial concentration of phage calculated from counts obtained from control tubes 11-14 plated at zero time was used as the base for calculating the percentage adsorption. With phage $42 \mathrm{E}, 50 \mu \mathrm{g} . \mathrm{CaCl}_{2} / \mathrm{ml}$. allowed maximum adsorption; $\mathrm{MgCl}_{2}$ could not replace $\mathrm{CaCl}_{2}$, and $\mathrm{NaCl}$ up to $800 \mu \mathrm{g} . / \mathrm{ml}$. was inactive.

The results obtained with 21 phages are given in Table 4 . Where no activity could be demonstrated for electrolyte in concentrations up to $1000 \mu \mathrm{g}$. $/ \mathrm{ml}$. a blank has been left in the table. Two phages, $42 \mathrm{C}$ and $44 \mathrm{~A}$, were so unstable in distilled water and salt solutions that no results were obtained. Phages 7, 42 B and 42E showed a specific requirement of calcium for adsorption, $90 \%$ adsorption occurring in $50 \mu \mathrm{g} . \mathrm{CaCl}_{2} / \mathrm{ml}$. and no adsorption in $\mathrm{MgCl}_{2}$ or $\mathrm{NaCl}$. Phage 47 required $150 \mu \mathrm{g}$. $\mathrm{CaCl}_{2} / \mathrm{ml}$. for adsorption; little adsorption 
occurred with a similar concentration of $\mathrm{MgCl}_{2}$ while with $800 \mu \mathrm{g} . \mathrm{NaCl} / \mathrm{ml}$. some adsorption took place.

Table 4. Minimum concentrations of $\mathrm{CaCl}_{2}, \mathrm{MgCl}_{2}$, and $\mathrm{NaCl}$ giving $90 \%$ adsorption of various phages in 20 min. at $37^{\circ}$

\begin{tabular}{|c|c|c|c|}
\hline \multirow[b]{2}{*}{ Phage } & \multicolumn{3}{|c|}{ Minimum concentration ( $\mu \mathrm{g} \cdot / \mathrm{ml}$.) } \\
\hline & $\mathrm{CaCl}_{2}$ & $\mathrm{MgCl}_{2}$ & $\mathrm{NaCl}$ \\
\hline $\mathbf{K}$ & 5 & 5 & 25 \\
\hline $\mathbf{3 A}, \mathbf{3 B}, \mathbf{3 C}$ & 10 & 10 & 400 \\
\hline $7,42 B, 42 E$ & $\mathbf{5 0}$ & - & - \\
\hline $6,47 A$ & 20 & 20 & 800 \\
\hline 29,52 & 400 & 400 & - \\
\hline $29 \mathrm{~A}, 52 \mathrm{~A}$ & 100 & 100 & - \\
\hline 31, 31B & 150 & 150 & 一 \\
\hline $42 D$ & 50 & 50 & - \\
\hline 44 & 200 & 200 & 一 \\
\hline 47 & 150 & - & 800 \\
\hline 47B & 5 & 5 & 100 \\
\hline $47 \mathrm{C}$ & 50 & 50 & 800 \\
\hline 51 & $\mathbf{5 0}$ & 50 & $1000^{*}$ \\
\hline
\end{tabular}

With the remainder of the typing phages, the $\mathrm{CaCl}_{2}$ requirements varied from 5 to $400 \mu \mathrm{g}$. $/ \mathrm{ml}$., and in all 5 to $400 \mu \mathrm{g}$. $\mathrm{MgCl}_{2} / \mathrm{ml}$. gave the same amount of adsorption. For phage $\mathbf{K}$, which is citrate-insensitive, concentrations of $5 \mu \mathrm{g}$. $\mathrm{CaCl}_{2}$ or $\mathrm{MgCl}_{2} / \mathrm{ml}$. or $25 \mu \mathrm{g}$. $\mathrm{NaCl} / \mathrm{ml}$. permitted $90 \%$ adsorption. These results indicate that the adsorption of phage $\mathbf{K}$ may be a simple electrolytic phenomenon which can be related to the valence of the cations used. With those citrate-sensitive phages in which adsorption in $\mathrm{NaCl}$ could be demonstrated, the relationship between valence and the concentration of electrolyte required for adsorption was not a geometric one. For example, phage $47 \mathrm{~B}$ required $100 \mu \mathrm{g}$. $\mathrm{NaCl} / \mathrm{ml}$. compared with $5 \mu \mathrm{g} . \mathrm{CaCl}_{2}$ or $\mathrm{MgCl}_{2} / \mathrm{ml}$. With the phages $29,29 \mathrm{~A}, 31,31 \mathrm{~B}, 42 \mathrm{D}, 44,52$ and $52 \mathrm{~A}$ no $\mathrm{NaCl}$ activity could be demonstrated in concentrations up to $1000 \mu \mathrm{g} . / \mathrm{ml}$.; higher concentrations could not be tested because they inactivated free phage. If the relationship between valence and cation requirements were a simple geometrical one, those phages having high $\mathrm{Ca}$ requirements would need almost astronomical amounts of $\mathrm{NaCl}$ for adsorption. On the other hand, phage 42 $\mathrm{D}$ which required $50 \mu \mathrm{g}$. $\mathrm{CaCl}_{2} / \mathrm{ml}$. might be expected to adsorb, at least partially, on to cells in $1000 \mu \mathrm{g}$. $\mathrm{NaCl} / \mathrm{ml}$. However, no viable phage could be recovered from such cells.

The adsorption tests also supplied evidence that the requirements of the phages were related to the phage and not to the cell surface. Phages $42 \mathrm{~B}$ and $47 \mathrm{C}$ are both propagated on staphylococcus strain 1163 , but whereas phage 47 C was adsorbed in $50 \mu \mathrm{g}$. $\mathrm{CaCl}_{2}$ or $\mathrm{MgCl}_{2} / \mathrm{ml}$., phage $42 \mathrm{~B}$ showed a specific requirement of $50 \mu \mathrm{g}$. $\mathrm{CaCl}_{2} / \mathrm{ml}$. Phages 31 and 44 required differing amounts of $\mathrm{CaCl}_{2}$ or $\mathrm{MgCl}_{2}$ for $90 \%$ adsorption on to strain 18. Finally phage $\mathrm{K}$ when 
adsorbed on to strain 145 required only $5 \mu \mathrm{g} . \mathrm{CaCl}_{2} / \mathrm{ml}$. as compared with phage 51, which required $50 \mu \mathrm{g} . / \mathrm{ml}$. for adsorption to this strain.

Estimates of the amount of viable phage recovered from sensitive cells infected with phages $3 \mathrm{~A}, 3 \mathrm{~B}$ or $3 \mathrm{C}$ in various concentrations of $\mathrm{CaCl}_{2}$, $\mathrm{MgCl}_{2}$ or $\mathrm{NaCl}$ provided some interesting information. The results obtained with phage $\mathbf{3 A}$ are given in Table 5 . With optimum amounts of $\mathrm{CaCl}_{2}$ or $\mathrm{MgCl}_{2}$ almost the whole amount of added phage could be recovered from the cells. With $400 \mu \mathrm{g}$. $\mathrm{NaCl} / \mathrm{ml}$., however, although the amount of free phage present in the supernatant indicated $95 \%$ adsorption, only $25 \%$ of adsorbed phage was recovered. Furthermore, there was no increasing yield of recoverable adsorbed phage with increasing concentrations of $\mathrm{NaCl}$.

Table 5. Adsorption of phage $\mathbf{3} \mathbf{A}$ in the presence of various concentrations of $\mathrm{CaCl}_{2}, \mathrm{MgCl}_{2}$, and $\mathrm{NaCl}$, showing amounts of unadsorbed phage in the supernatants and of adsorbed phage recovered from the cells

Quantities of electrolytes in $\mu \mathrm{g}$./ml. solution.

\begin{tabular}{|c|c|c|}
\hline \multirow{3}{*}{ Tube No. } & \multicolumn{2}{|c|}{$\begin{array}{c}\text { Contents } \\
\text { Cells }+ \text { phage in }\end{array}$} \\
\hline & Distilled & water \\
\hline & $\mathrm{CaCl}_{2}$ & 5 \\
\hline 3 & & 10 \\
\hline 4 & $\mathrm{MgCl}_{2}$ & 10 \\
\hline 5 & & 20 \\
\hline 6 & $\mathrm{NaCl}$ & 100 \\
\hline 7 & & 200 \\
\hline 8 & & 400 \\
\hline 9 & & 800 \\
\hline
\end{tabular}

\begin{tabular}{|c|c|}
\hline \multicolumn{2}{|c|}{ Plaque counts } \\
\hline Free phage & Adsorbed phage \\
\hline $212 ; 250$ & 14 \\
\hline $33 ; 41$ & $152 ; 121$ \\
\hline 5 & $170 ; 130$ \\
\hline $10 ; 11$ & $136 ; 170$ \\
\hline $4 ;$ & $158 ; 210$ \\
\hline $118 ; 80$ & $49 ; 68$ \\
\hline $37 ; 29$ & $32 ; 43$ \\
\hline 9 & $53 ; 72$ \\
\hline $18 ; 18$ & $55 ; 75$ \\
\hline
\end{tabular}

These results resemble those obtained by Puck (1949) who found that coli phage $\mathbf{T} 1$ diluted in distilled water and adsorbed on to coli cells in the absence of calcium ions could not be recovered. Puck ascribed his finding to "sensitization' of phage by dilution in distilled water or phosphate buffer, and suggested that this sensitization produces a block in some step in the virus cycle which occurs after adsorption. This step may be that of penetration of the cell as distinct from adsorption on to the cell surface. If this be so, the recovery of viable phage from staphylococcal cells when adsorption has taken place in $\mathrm{NaCl}$ might be due to the cells themselves providing sufficient calcium to allow 'activation' and penetration of some adsorbed phage. Since constant amounts of phage $\mathbf{3 A}$ were recovered from constant numbers of cells infected in increasing concentrations of $\mathrm{NaCl}$, there is some evidence for this view. Cells grown in broth containing citrate should be lacking in this postulated available calcium and, if infected in $\mathrm{NaCl}$, no phage should be recoverable from them. An experiment was set up in which the propagating strain for phage $\mathbf{3 A}$ was grown in $0.5 \%$ citrate broth for $5 \mathrm{hr}$., the cells washed in distilled water and resuspended therein. From these cells no phage 
was recovered when adsorption took place in $\mathrm{NaCl}$, while in $\mathrm{CaCl}_{2}$ all the phage adsorbed was recovered; the results of a typical experiment are given in Table 6.

Table 6. Percentage adsorption and percentage recovery of phage 3A adsorbed on to cells grown in citrate broth and infected in $\mathrm{CaCl}_{2}$ or various concentrations of $\mathrm{NaCl}$

Quantities of electrolytes in $\mu \mathrm{g}$./ml. solution.

$\begin{array}{cccc}\text { Tube No. } & \begin{array}{c}\text { Contents } \\ \text { Cells + phage in }\end{array} & \begin{array}{c}\text { Adsorption } \\ (\%)\end{array} & \begin{array}{c}\text { Recovery } \\ (\%)\end{array} \\ 1 & \text { Distilled water } & 0 & 0 \\ 2 & \mathrm{CaCl}_{\mathbf{2}} \mathbf{5 0} & \mathbf{9 9} & 100 \\ 3 & \mathrm{NaCl}^{100} & 60 & 0 \\ 4 & 200 & 80 & 0 \\ 5 & 400 & 90 & 0 \\ 6 & \mathbf{8 0 0} & 100 & 0\end{array}$

\section{DISCUSSION}

Phage adsorption was originally regarded as a relatively simple process in which specific receptor structures of phage and cell surfaces were brought together by non-specific electrolytic forces. However, the observations of Anderson (1945) on the tryptophan co-factor requirements of certain coli phages and of Delbrück (1948) on a $\mathrm{Ca}^{++}$-requiring mutant coli phage indicated that the electrolyte theory could no longer be regarded as sufficient and that, besides electrical forces, enzymic reactions involving either phage or cell surface or both must be postulated.

With the staphylococcal phages used here the adsorption process may be equally complex. With two exceptions, adsorption of these phages was inhibited by citrate although adequate amounts of electrolyte were present had the adsorption been a simple electrical phenomenon. With phages 7 , $42 \mathrm{~B}$ and $42 \mathrm{E}$, a specific co-factor requirement for $\mathrm{Ca}^{++}$was demonstrated. With the other phages $\mathrm{Mg}^{++}$could be substituted for $\mathrm{Ca}^{++}$. There was also evidence that each phage had a characteristic $\mathrm{Ca}^{++}$requirement, rather than that the $\mathrm{Ca}^{++}$requirement was related to the nature of the bacterial cell surface. The inactivation of some phages by citrate in broth suggests that citrate may combine with $\mathrm{Ca}^{++}$on the surface of the phage particle and so block the sites involved in adsorption.

With phages $\mathrm{K}$ and 51 there was neither inactivation of free phage by citrate nor inhibition of adsorption. The requirements of phage $\mathrm{K}$ were directly related to the valence of the ions used. With phage 51 this could not be demonstrated experimentally since the amount of $\mathrm{NaCl}$ 'theoretically' required inactivated the phage in absence of the stabilizing action of nutrient broth.

The fact that certain of the phages which had low requirements of divalent cations adsorbed in $\mathrm{NaCl}$ does not invalidate the hypothesis that divalent 
cations, particularly $\mathrm{Ca}^{++}$, are of primary importance in adsorption. There was a lower recovery of viable phage from cells infected in $\mathrm{NaCl}$, and furthermore there was complete loss of adsorbed phage when the cells had been previously grown in citrate broth. This suggests that under certain conditions the cell itself may supply the required $\mathrm{Ca}^{++}$or $\mathrm{Mg}^{++}$and $\mathrm{NaCl}$ may merely provide the electrical conditions necessary for apposition of cell and phage. The experimental results, therefore, suggest that $\mathrm{Ca}^{++}$is required for penetration, but they do not exclude the possibility that this is also involved in an early step in the growth cycle following penetration of the cell.

The conclusion that $\mathrm{Ca}^{++}$is important in phage adsorption is of interest in the light of the findings of Burnet and his associates on the importance of $\mathrm{Ca}^{++}$in the reactions of influenza virus, of the receptor-destroying enzyme of the cholera vibrio with erythrocyte surfaces, and the mucoid inhibitors of haemagglutination (Edney, 1949). The adsorption phenomena involved in these reactions appear to be enzymic in nature. The present observations with staphylococcal phages suggest that, at least for some of them, adsorption and penetration may also be enzymic.

\section{REFERENCES}

Adams, M. H. (1949). The calcium requirement of coli phage T5. J. Immunol. 62, 505.

Anderson, T. F. (1945). The role of tryptophane in the adsorption of two bacterial viruses on their host, E. coli. J. cell. \& comp. Phys. 25, 17.

Burnet, F. M. (1933). The classification of dysentery-coli bacteriophages. III. A correlation of the serological classification with certain biochemical tests. J. Path. Bact. 37, 179.

Burnet, F. M. \& Lush, D. (1935). The staphylococcal bacteriophages. J. Path. Bact. 40, 455 .

CoHen, S. S. (1949). Growth requirements of bacterial viruses. Bact. Rev. 13, 1.

DeLBRücK, M. (1948). Biochemical mutants of bacterial viruses. J. Bact. 56, 1.

EDNEy, M. (1949). The influence of calcium ion on the reactions of the $V$. cholerae enzyme R.D.E. and influenza virus with specific mucopolysaccharides. Aust. J. exp. Biol. med. Sci. 27, 252.

Elford,W. J. \& ANDrewes, C. H. (1932). The 'killing' of bacteria by bacteriophage. Brit. J. exp. Path. 13, 13.

Puck, T. T. (1949). A reversible transformation of T1 bacteriophage. J. Bact. 57, 647.

Rountree, P. M. (1947). Staphylococcal bacteriophages. II. Bacteriophage absorption by staphylococci. Aust. J. exp. Biol. med. Sci. 25, 203.

Rountree, P. M. (1949). The serological differentiation of staphylococcal bacteriophages. J. gen. Microbiol. 3, 164.

Williams Smith, H. (1948). Calcium-deficient media: their effect on phage action. Nature, Lond., $161,397$.

Wilson, G. S. \& Atrinson, J. D. (1945). Typing of staphylococci by the bacteriophage method. Lancet, i, 647 . 